ФІЗИЧНЕ ВИХОВАННЯ РІЗНИХ ГРУП

\title{
НАСЕЛЕННЯ
}

\section{DIRECTIONS FOR IMPROVING PHYSICAL EDUCATION OF PUPILS IN UKRAINIAN ESTABLISHMENTS OF GENERAL SECONDARY EDUCATION ON THE BASIS OF EXTERNAL EXPERIENCE}

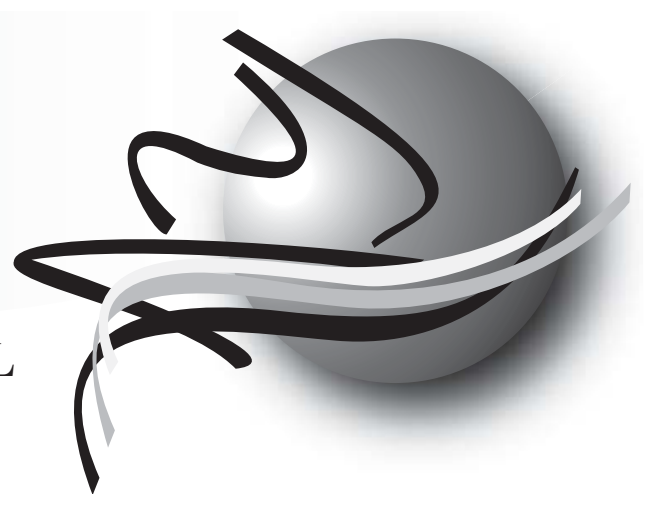

\author{
Moskalenko Nataliial, Yakovenko Artem ${ }^{l}$, \\ Ovcharenko Serhii ${ }^{1}$, Natalija Gustavson ${ }^{2}$ \\ ${ }^{1}$ Dnipro State Academy of Physical Culture and Sports \\ ${ }^{2}$ Centre for Educational Assessment \\ Faculty of Educational Sciences
}

DOI: $10.32540 / 2071-1476-2019-3-128$

\begin{abstract}
Annotation
Introduction and purpose of the study. The article is devoted to the actual problem of finding ways to optimize the system of physical education of Ukrainian schoolchildren based on the study of the characteristics of the organization and implementation of the process of physical education in selected countries of Europe, Asia and America. The hypothesis of the study is based on the assumption that borrowing certain provisions of the positive experience of organizing physical education for schoolchildren in foreign countries with adaptation to the peculiarities of the domestic system will improve the process of physical education in Ukrainian institutions of general secondary education. The goal is to determine the direction of improving the physical education of Ukrainian schoolchildren on the basis of extrapolation of foreign experience.
\end{abstract}

Material and methods. The studies were conducted in Pridneprovsk State Academy of Physical Culture and Sports. The study used the following methods: theoretical analysis and synthesis of data from scientific and methodological literature and documentary materials, the method of comparison, the method of system analysis.

Results. The directions for improving the physical education of institutions of general secondary education of Ukraine based on international experience are as follows: creating an appropriate legal framework, promoting national standards of physical culture, creating flexible curricula with the ability to take into account all aspects of child development and the region, correction and expansion subject, ensuring compliance with the recommended norms of physical activity, high-quality staffing, the development of adequate approaches to the subject of teaching and a comprehensive assessment of students' achievements.

Conclusions. Analysis of literary sources and documentary materials showed the value and the possibility of using foreign experience in the practice of Ukrainian secondary education.

Keywords: foreign countries, experience, extrapolation, prospects, schoolchildren.

\section{Анотація}

Вступ і мета дослідження. Стаття присвячена актуальній проблемі пошуку шляхів оптимізації системи фізичного виховання українських школярів на основі вивчення особливостей організації та здійснення процесу фізичного виховання окремих країн Свропи, Азії, Америки. Гіпотеза дослідження грунтується на припущенні, що запозичення окремих положень позитивного досвіду організації фізичного виховання школярів зарубіжних країн з адаптацією до особливостей вітчизняної системи дозволить удосконалити процес фізичного виховання в українських закладах загальної середньої освіти. Мета - визначити напрями удосконалення фізичного виховання учнів закладів загальної середньої освіти України на основі екстраполяції 
зарубіжного досвіду.

Матеріал і методи. Дослідження проводились у Придніпровській державній академії фізичної культури і спорту. У ході дослідження використано такі методи: теоретичний аналіз та узагальнення даних науковометодичної літератури та документальних матеріалів, метод порівняння, метод системного аналізу.

Результати. Визначено напрями удосконалення фізичного виховання закладів загальної середньої освіти України на основі зарубіжного досвіду, що полягають у наступному: створення відповідної законодавчої бази, просування національних стандартів фізичної культури, створення гнучких навчальних програм 3 можливістю урахування всіх аспектів розвитку дитини та регіону країни, корекція та розширення спрямованості предмету, забезпечення дотримання рекомендованих норм рухової активності, високоякісне кадрове забезпечення, розробка адекватних підходів до викладання предмету та комплексна оцінка навчальних досягнень здобувачів освіти.

Висновки. Аналіз літературних джерел і документальних матеріалів показав цінність і можливість використання зарубіжного досвіду в практиці української середньої освіти.

Ключові слова: зарубіжні країни, досвід, екстраполяція, перспективи, школярі.

\section{Аннотация}

Введение и цель исследования. Статья посвящена актуальной проблеме поиска путей оптимизации системы физического воспитания украинских школьников на основе изучения особенностей организации и осуществления процесса физического воспитания в отдельных странах Европы, Азии, Америки. Гипотеза исследования основывается на предположении, что заимствование отдельных положений положительного опыта организации физического воспитания школьников зарубежных стран с адаптацией к особенностям отечественной системы позволит усовершенствовать процесс физического воспитания в украинских заведениях общего среднего образования. Цель - определить направления совершенствования физического воспитания учащихся учреждений общего среднего образования Украины на основе экстраполяции зарубежного опыта.

Материал и методы. Исследования проводились в Приднепровской государственной академии физической культуры и спорта. В ходе исследования использованы следующие методы: теоретический анализ и обобщение данных научно-методической литературы и документальных материалов, метод сравнения, метод системного анализа.

Результаты. Определены направления совершенствования физического воспитания учреждений общего среднего образования Украины на основе зарубежного опыта, которые заключаются в следующем: создание соответствующей законодательной базы, продвижение национальных стандартов физической культуры, создание гибких учебных программ с возможностью учета всех аспектов развития ребенка и региона страны, коррекция и расширение направленности предмета, обеспечение соблюдения рекомендуемых норм двигательной активности, высококачественное кадровое обеспечение, разработка адекватных подходов к преподаванию предмета и комплексная оценка учебных достижений учащихся.

Выводы. Анализ литературных источников и документальных материалов показал ценность и возможность использования зарубежного опыта в практике украинского среднего образования.

Ключевые слова: зарубежные страны, опыт, экстраполяция, перспективы, школьники.

Introduction. One of the driving forces of progress in any field of human activity and knowledge is the synthesis of the accumulated world experience. In conditions of the reform of the education system in our country, the study and analysis of trends in the development of education abroad is becoming increasingly important.

An important source of defining the current strategy for the development of the field of physical education in Ukraine is the analysis of best practices in the organization

(C) Moskalenko N., Yakovenko A., Ovcharenko S., Natalija G., 2019 of the educational process, the study of the regularities and peculiarities of this important component of the educational sphere in different countries of the world (Бобровник, 2014; Пангелова, Красов, 2016).

The development of the physical education of children and young people in the education system, bringing it to the world level should be carried out in the context of wide integration into the international educational system and the exchange of best practices.

The organization of physical education and sports in the schools of European countries is the subject of the study of foreign experts such as C. Annerstedt (2001), R. Naul (2002), E. Pospech, M. Shapeliavy, Yu. Voynar (2002), K. Hardman (2008 ), C. Murphy, A. Routen, S. Tones (2013), Physical Education in Asia have devoted their research Do Ken Wu (2000), Lee Van Teck (2005), T. Nakai, M.W. Meltzer (2005), M.M. Zaburdaieva (2007), Wang Jing, A.S. Bondar (2013), Hu Liifi (2013), A. Kajanus (2016), V.D. Ivanov, N.O. Salkov (2017), 
peculiarities of physical education in American schools were studied by K. Hardman (2014), C. Kelso (2013), M. Kilborn, J. Lorusso, N. Fransis (2016) and others.

In addition, domestic experts also studied the organization and methods of physical education in foreign countries (Volkov, 2007; Vilchkovsky, 2014; Turchik, 2005; Hloba, 2012; Anikieiev, 2012; Mandiuk, 2013; Zhdanova, Chekhovskaya, Fliak, 2015; Panhelova, 2017, etc.). This indicates the presence of a sufficient number of sources and the basis for learning the features of the system of physical education in foreign countries.

The end of the 20th - the beginning of the 21 st century was a time of serious trials that took place in schools around the world, including in Ukraine, the concepts and systems of school education in the field of physical education and sport, as well as the search for new, more effective ways, forms and methods of teaching physical education. It is known that the only model of physical education and sports in schools of foreign countries does not exist, but the accumulation of knowledge on various aspects of the organization of physical education of students from other countries will contribute to the creation of the most effective domestic model taking into account national peculiarities (Турчик, 2017; Яковенко, 2018).

Ukraine is undergoing an important stage in reforming the sphere of education and, in particular, physical education. As the experience of other countries shows, now it is necessary to concentrate efforts on the creation of a powerful system of harmonious development of students with a high level of motor and social competence.

The hypothesis of the study is based on the assumption that the borrowing of certain provisions of the positive experience of organizing the physical education of pupils of foreign countries with adaptation to the peculiarities of the domestic system will improve the process of physical education in Ukrainian institutions of general secondary education.

The purpose - to determine the directions of improvement of physical education of pupils of institutions of general secondary education of Ukraine on the basis of extrapolation of foreign experience.

Material and methods. Research conducted in the Dnipro State Academy of Physical Culture and Sports. In the course of the research, the following methods were used: theoretical analysis and generalization of data of scientific-methodical literature and documentary materials, method of comparison, method of system analysis.

Results and discussions. The study of foreign experience in ensuring the quality and features of the organization of physical education of pupils in certain countries of Europe, Asia and America allowed us to outline ways to improve the system of physical education of schoolchildren in Ukraine.

One of the main areas is state support for the field of physical education and the creation of an appropriate legislative framework, as well as a system for monitoring compliance with requirements and directives. That is, the necessary step is to ensure regulation of activities in the field of physical culture and sports by the state. An example of such a system is the countries of Asia, which have a well-thought out system of laws and mechanisms for their implementation and compliance.

It is also necessary to create an appropriate legal framework based on the principles of the European Sport Charter, which provides for: the ability of every individual to engage in sports, to guarantee all young people the opportunity to acquire knowledge of physical education and to master basic physical skills, a guarantee of opportunities for sports and physical activity in safe for health conditions, a guarantee of the training of highly skilled teachers in this area in all educational institutions, a guarantee of appropriate opportunities for continuing encouraging the development of links between schools or other educational institutions, school and local sports clubs, and influencing public opinion so that parents, trainers, educators and managers stimulate young people to have regular physical exercises, combining sports and moral education of pupils etc.

Another step in the documentary foundation in the field of physical culture and sports should be the development of national and regional strategies for physical education and physical activity of schoolchildren. An example of such directives can be the United States of America, which introduced the "Rules of Physical Activity of Americans", the initiative "Let's move on in school!" and so on. For our country, one can also propose the development of guidelines and rules of physical activity, which should reflect ways to increase and provide motor activity of the population, as well as the creation of government initiatives on motor activity, which include an integrated approach to promoting physical activity in school: providing various opportunities realization of physical activity in school (lesson and extra-curricular forms of classes, activities in the mode of the day, before and after training sessions) participation of family in physical activity, opportunities the application of knowledge acquired in the course of physical education in practice.

The experience of many countries proved the possibility of using national standards of physical education, which reflect different areas of competence of students - motor, cognitive, social.

Therefore, the system of physical education of schoolchildren in Ukraine should strive to comply with the European framework for qualitative physical education (Vass, 
Boronyai, Csanyi, 2018), providing:

- the presence of healthy pupils who have the ability and willingness to study, and who are supported by family and community education;

- healthy, safe, secure, genderbased environment, as well as providing sufficient resources and facilities for learning;

- content reflected in curricula and materials that promotes basic motor skills, healthy life skills, as well as knowledge of areas such as health, nutrition, disease prevention;

- processes by which teachers use child-centered approaches to well-trained schools, adequate assessment of skills for successful learning;

- results that include knowledge, skills, attitudes according to learning goals, social activity.

Accordingly, it is possible to foresee the introduction of a standard-oriented approach covering different spheres of the child: competence in movement, involvement in health physical activity, awareness and use of health rules, selfawareness and self-governance, problem solving and constructive thinking.

In our opinion, for the system of physical education of Ukrainian schools, a comprehensive approach to the development of the child is valuable, which is the basis of the national standards for the physical education of foreign countries, which is based on a gradual increase of awareness about the choice of different forms and means of physical education from primary to middle and senior schools. Primary forms pupils must master the basics of motor activity from the types of sports offered by the school curriculum, to create ideas about basic physical culture concepts, to identify responsible behavior during physical activity, to describe positive feelings of movement. For middle school pupils, it is necessary to foresee mastering an arsenal of technical and tactical actions in various sports and physical activity, their planning and application, active participation in extra-curricular forms of physical education, the adoption of oneself and others, their promotion and encouragement to physical activity. Senior pupils should develop the ability to independently plan, organize and control physical activity, to demonstrate advanced competence and knowledge in various types of physical exercises, demonstrate self-management skills, accept and understand the differences in the physical development of others, realize the need for self-expression and enjoyment of physical activity. As a result, a school graduate appears educated personality, able to consciously use different types of motor activity throughout life.

One of the important conditions for improving the efficiency of physical education is the creation of flexible curricula that will allow the teacher to make appropriate adjustments depending on the regional features of the country, climatic conditions, financial situation, age and gender of those involved in national values and traditions. It is necessary to provide the teacher with the opportunity to create an author's component of the program of physical education, taking into account the peculiarities of building an educational process in a particular institution of general secondary education. You can also propose the development of additional physical education programs with an emphasis on creative abilities, aesthetic and artistic components of motor activity. This approach is used in schools in Germany, Poland, and the United Kingdom.

To increase the number of sports disciplines offered in physical education curricula, additional sources of funding, such as non-state funding, grant programs, as practiced in the US, Japan, and Finland, should be involved. This, in turn, will help to create the proper infrastructure for school physical education.

Programs on the subject "Physical Culture" should correspond to the concept of "motor education", which determines the ability to use the culture of movements throughout life, the diverse development of personality, ensuring interpersonal communication with the outside world, to take into account the basic European concepts of physical education, which include: sports education, motor education ("person-to-person interaction training") and knowledge of health. Today, models of physical education with a close relationship with health care are relevant, involving cooperation between school administrations, teachers, parents, sports clubs, health care professionals with the aim of providing pupils with the necessary knowledge and raising the level of health to safe. Motor education has been cultivated in Germany for more than fifty years, and the combination of physical education with healthcare is practiced in Finland, Japan, China.

When creating physical education curricula it is also necessary to take into account the pupil's health, the quality of medical care, the ability to formulate sanitary skills and prevention skills for common diseases among pupils.

The main goal and objectives of physical education of schoolchildren must be consistent with global trends. The tasks of the subject "Physical Culture" for institutions of general secondary education of Ukraine have no gradualness and deepening from primary to secondary and high school, and do not cover all possibilities of influence of physical education on the person. Therefore, in our opinion, the main tasks of the subject should be added to the task of preparing for physical activity throughout life, forming a holistic person, ready to learn and enriching the experience of motor activity, the development of interpersonal skills, abilities to solve problem tasks, self-expression, as presented in the physical education tasks of students of European countries. 
Increasing the effectiveness of the learning process will be facilitated by the creation of rigorous requirements for providing time for motor activity in compulsory tuition and non-formal forms of occupation (60 minutes per day). It is necessary to meet the needs and interests of children through the introduction of modern types of motor activity. With the lack of knowledge of physical education teachers in the latest sports, sports clubs and centers can be involved. And to improve the skills of teachers, it is necessary to create a wide range of training seminars and courses of theoretical and practical orientation with the aim of training and retraining of personnel for mastering modern methods of education and upbringing. Special attention is paid to the training of personnel in China, Japan, Poland, USA.

Exercise during extracurricular hours should become mandatory, as proposed to pupils of Polish schools, and provide pupils with the opportunity to choose forms and means (recreational classes, mobile and sports games, corrective gymnastics, physical therapy, tourism, etc.). This will realize the interests and needs of pupils to different types of sports or recreation.

To create a positive image of the country at the world level, it is necessary to provide pupils with physical activity during the entire period of study, and, accordingly, a high level of physical fitness and sporting achievements.

In addition to physical preparedness, pupils should have a high level of theoretical training and a system of knowledge of physical education, which, with the correct presentation of the material, will allow them to apply the acquired knowledge in life. Therefore, it is possible to recommend modern forms of providing theoretical information - master classes, creative laboratories, research work, etc., and the main methods of teaching should become interactive - those that require the interaction and involvement of all participants in the learning process (brainstorming, project method, clusters, comparative charts , puzzles and others). It should be noted that in most foreign countries, the programs of physical education contain a theoretical component.

The high quality of the system of physical education will also be ensured by the appropriate level of qualification of a teacher of physical education, ie he must have a professional education in a specialty (bachelor in elementary school, master - in middle and senior). In addition, it is possible to introduce the teaching of physical education in the elementary school of two teachers simultaneously - a class teacher and a teacher of physical culture, as is practiced in the UK. To do this, educational materials for the preparation of primary school teachers should be included in the teaching materials on the basic principles of physical education, which will allow the teacher to become a universal.

In foreign schools, the main approach to teaching students is competent, which identifies the integrated ability of the individual, which includes knowledge, experience, values, attitudes and can be realized in practice. At the present stage, the main task is to introduce and expand a competency approach at all levels of education.

In the development of approaches to physical education, the personality of the child, his interests and needs for realization in the field of physical culture should be taken into account first of all. The results of physical education should be related to life, that is, at classes it is necessary to form skills to work in a team, communicative skills, skills of social interaction, self-government, etc.

Complexity of the system of physical education will promote the implementation of an integrated approach, that is, the acquisition of knowledge from other educational subjects in physical education lessons and vice versa; providing interdisciplinary connections with math, reading, visual arts, basics of life safety, etc. This approach is presented in educational institutions of European countries.

The introduction of modern means and techniques of motor activity will help to increase the motivation of schoolchildren for motor activity and will provide an opportunity to use them throughout their lives. In the United Kingdom, Finland, the United States is constantly expanding the list of types of motor activity, presented in the program of physical education, as well as in extracurricular activities. But when forming students' need for physical activity, it is necessary to take into account the specifics of the national motor culture.

The result of studying the subject "Physical Culture" is the quality of knowledge and skills of students. Therefore, assessment of school achievements of schoolchildren should have a comprehensive approach, which includes: assessment of the psychomotor component (evaluation of motor skills and skills from the program material, the level of development of physical qualities, personal progress in physical fitness), the cognitive component (assessment of the level of knowledge and its application to practice), affective component (assessment of pupils' behavior, their relation to the subject, involvement in exercises, participation, preparation for the lesson, cooperative actions, behavior, etc.). Approximately the same range of criteria for evaluating academic achievement of students is presented in the countries we studied in Europe, Asia and America.

The assessment system should include the use of different methods, tools and criteria: observation, tests, portfolio, student passport, student self-assessment, general school report. This will allow you to track the effectiveness of the teacher-selected approaches.

(C) Moskalenko N., Yakovenko A., Ovcharenko S., Natalija G., 2019 
Prospects for improving the system of physical education of Ukrainian schools

\begin{tabular}{|c|c|}
\hline Quality Indicators & Activities and directions of improvement \\
\hline Legislative base & $\begin{array}{l}\text { - state regulation of activity in the field of physical education; } \\
\text { - creation of laws, regulations, directives that take into account the principles of the Euro- } \\
\text { pean Sport Charter; } \\
\text { - national strategies and initiatives to support and promote physical activity of the popula- } \\
\text { tion, in particular schoolchildren; } \\
\text { - guidelines and rules for improving physical activity }\end{array}$ \\
\hline National Standards & $\begin{array}{l}\text { - introduction of standards of physical education that are in line with the European } \\
\text { framework for qualitative physical education }\end{array}$ \\
\hline Curriculums, programs & $\begin{array}{l}\text { - creation of flexible curricula that allow the teacher to take into account regional fea- } \\
\text { tures, climatic conditions, material situation, age and gender of children, national values } \\
\text { and traditions; } \\
\text { - the possibility of creating author's programs by teachers taking into account the pe- } \\
\text { culiarities of the educational process at the institution of general secondary education; } \\
\text { - in the basis of programs - the concept of "motor education", the culture of movements, } \\
\text { the combination of conceptual knowledge in the field of sports, motor education, health } \\
\text { education; } \\
\text { - additional physical activity programs with an emphasis on creative abilities; } \\
\text { - taking into account the health status of students, medical care, the formation of sani- } \\
\text { tary skills and skills for the prevention of common diseases among pupils; } \\
\text {-use of modern methods and forms of theoretical preparation for the formation of a } \\
\text { system of knowledge on the subject }\end{array}$ \\
\hline $\begin{array}{l}\text { Direction, purpose and } \\
\text { object of the subject }\end{array}$ & $\begin{array}{l}\text { - conformity to global trends taking into account the national motor culture; } \\
\text { - expansion of the range of tasks to which it is necessary to add preparation for the imple- } \\
\text { mentation of physical activity throughout life, the formation of a coherent person (the } \\
\text { interaction of the body and mind), ready for training, the development of interpersonal } \\
\text { skills, self-expression, the ability to design and solve problem tasks }\end{array}$ \\
\hline $\begin{array}{l}\text { Number of hours to } \\
\text { study the subject }\end{array}$ & $\begin{array}{l}\text { - compliance with recommended motor activity standards; } \\
\text { - providing pupils with compulsory lesson and extra-curricular forms of training; } \\
\text {-providing pupils with the choice of the type of motor activity in extra-curricular time } \\
\text { (sports direction, recreation direction, treatment and correction, etc.) }\end{array}$ \\
\hline Personnel support & $\begin{array}{l}\text { - specialists with professional training at all levels of education; } \\
\text { - possibilities for two teachers to take classes at elementary school (class teacher and } \\
\text { teacher of physical education); } \\
\text { - inclusion in the educational curricula of primary school teachers of educational mate- } \\
\text { rial on the peculiarities of conducting physical education lessons; } \\
\text { - mastering teachers and future teachers with modern methods of teaching and upbring- } \\
\text { ing, their ability to apply them; } \\
\text { - holding special training courses for theoretical and practical orientation for teachers }\end{array}$ \\
\hline $\begin{array}{l}\text { Methods and ap- } \\
\text { proaches }\end{array}$ & $\begin{array}{l}\text { - competency approach, which involves focusing on the acquisition of key and substan- } \\
\text { tive competencies; } \\
\text { - the focus of the pupil's personality, his interests and needs; } \\
\text { - an integrated approach, the introduction of theoretical knowledge of physical culture } \\
\text { into other subjects (history, biology, chemistry, life safety, etc.) and vice versa; } \\
\text { - close connection with health care; } \\
\text { - introduction of modern means and methods of training that raise and sustain the pupil's } \\
\text { interest in learning }\end{array}$ \\
\hline & $\begin{array}{l}\text { - an integrated approach that includes: assessment of psychomotor (motor skills and abili- } \\
\text { ties, physical qualities, personal progress in physical fitness), cognitive (level of knowl- } \\
\text { edge and their application in practice), affective (attitude towards lessons, attendance, } \\
\text { participation, preparedness for lesson, behavior, interaction with other) components; }\end{array}$ \\
\hline
\end{tabular}

(C) Moskalenko N., Yakovenko A.,

Ovcharenko S., Natalija G., 2019 


\begin{tabular}{|c|l|}
\hline $\begin{array}{c}\text { Assessment of educa- } \\
\text { tional achievements }\end{array}$ & $\begin{array}{l}\text { - different methods, tools and evaluation criteria; } \\
\text { - constant monitoring of indicators of physical condition of pupils with accumulation } \\
\text { structure; } \\
\text { - the final exam on physical education, the results of which are taken into account when } \\
\text { entering higher education institutions }\end{array}$ \\
\hline
\end{tabular}

An important direction in improving the efficiency of physical education of schoolchildren is the constant monitoring of the indicators of their physical condition, which has a cumulative structure and makes it possible to trace changes in indicators over a specified period. It will also make it possible to make adjustments to the curriculum, to implement an individual approach, to provide guidance on planning and implementation of motor activity, and to have feedback from parents and inform them about the state of children.

The creation of a high rating of the subject "Physical Culture" will facilitate the introduction of a compulsory exam at the final examinations, the results of which will be taken into account when entering to the Higher Education Institution, spred in China and France.

The general directions of improvement of the system of physical education in Ukraine are presented in Table 1.

Consequently, it can be argued that the study of foreign experience in the organization of physical education of schoolchildren had a certain value for optimization of physical education in Ukraine, especially on the way of the state entering the European educational space.

Conclusions. Analysis and generalization of the experience of organizing physical education in the schools of certain countries of Europe, Asia and America, as well as the identification of weak links in providing a system of physical education in Ukrainian schools, have allowed us to determine the directions of its optimization. These include: the creation of an appropriate legislative framework, promotion of national standards of physical culture, flexible curricula with the ability to take into account all aspects of child development and the region of the country, correction and widening of the subject orientation, ensuring compliance with the recommended norms of motor activity, high-quality staffing, development of adequate approaches to the teaching of the subject and a comprehensive assessment of educational achievements of the educational curriculum.

Prospects for further research are to determine the effectiveness of the proposed measures to improve the system of physical education in Ukraine.

Conflict of interest. The authors state that there is no conflict of interest.

\section{Література}

1. Аникеев Д.М. Формирование современных концепций физического воспитания в странах Западной Европы во II половине XX - начале XXI века. Физическое воспитание студентов. 2012. № 4. C. 9-12.

2. Бобровник C.I. Концепції сучасного фізичного виховання школярів. Педагогічні науки. 2014. Вип. 117. С. 15-21.

3. Ван Цзин, Бондарь А.С. Организация физического воспитания детей и молодежи в Китайской Народной Республике. Слобожанський науково-спортивний вісник. 2013. №5 (38). С. 45-48.

4. Вільчковський Е., Пасічник В. Фізичне виховання в школах Греції. Фізичне виховання, спорт і культура здоров'я у сучасному суспільстві. 2015. №3 (31). С. 10-14.

5. Волков Л., Пангелова Н. Спортивный стиль жизни как основа олимпийского образования детей и молодежи различных регионов мира. Наука в олимпийском спорте. 2007. С. 110 -114.

6. Глоба Г.В. Система фізичного виховання в школах Китаю. Педагогіка, психологія та медико-біологічні проблеми фізичного виховання і спор-

\section{References}

1. Anikeev D. (2012). Formation of modern concepts of physical education in Western Europe in the II half of the twentieth - early XXI century. Physical education of students, 4, 9-12. (In Russian).

2. Bobrovnyk S. (2014). Concepts of modern physical education of schoolchildren. Pedagogical sciences, 117, 15-21. (In Ukrainian).

3. Van Tszin, Bondar A. (2013). Organization of physical education of children and youth in the People's Republic of China. Slobozhansky Scientific and Sport Herald, 5 (38), 45-48. (In Russian).

4. Vilchkovskiy E., Pasichnik V. (2015). Physical education in schools of Greece. Physical education, sport and health culture in modern society, 3 (31), 10-14. (In Ukrainian).

5. Volkov L., Pangelova N. (2007). Sports lifestyle as the basis of the Olympic education of children and youth in various regions of the world. Science in Olympic sports, 110-114. (In Russian).

6. Globa G. (2012). The system of physical education in schools in China. Pedagogy, psychology and medical-biological problems of physical training and sports, 10, 16-19. (In Ukrainian). 
ту. 2012. №10. С. 16-19.

7. До Кеон Ву. Управление физической подготовкой в странах Дальневосточной Азии: автореф. дис. ... канд. пед. наук.: 13.00.04. СПб., 2000. 20 с.

8. Жданова О., Чеховська Л., Фляк А. Фізичне виховання в школах країн Європи. Молода спортивна наука України. 2015. Т. 2. С. 311-319.

9. Забурдаева М.Н. Структурно-содержательные компоненты учебных программ по физическому воспитанию учащихся школ России и стран Востока: дис. ... канд..пед.наук: 13.00.04. Санкт-Петербург, 2007. 240 с.

10. Иванов В.Д., Салькова Н.А. Особенности физической культуры и спорта в странах Азии. Физическая культура. Спорт. Туризм. Двигательная рекреация. 2017. Т.2, № 1. С. 32-35.

11. Ли Ван Тэк. Цели и содержание физического воспитания учащихся общеобразовательных школ стран Азии (Япония, Корея, Китай): автореф. дис. ... канд.пед.наук: 13.00.04. Рос. гос. пед. ун-т им. А.И. Герцена. Санкт-Петербург, 2005. $26 \mathrm{c}$.

12. Лифей Ху. Характеристика особенностей функционирования системы физической культуры и спорта в КНР (1995-2012 гг.). Фізичне виховання, спорт і культура здоров'я у сучасному суспільстві. 2013. № 4 (24). С. 14-18.

13. Мандюк А. Фізичне виховання в системі середньої освіти США. Спортивний вісник Придніпров’я. 2013. № 2. С. 210-213.

14. Пангелова Н., Власова С. Зарубіжний досвід організації фізичного виховання в загальноосвітніх школах. Спортивний вісник Придніпров я. 2017. № 1. С. 215-221.

15. Пангелова Н., Красов О. Авторські школи і концепції фізичного виховання дітей дошкільного віку у новий час (середина XVII - початок XX ст.). Спортивний вісник Придніпров'я. 2017. № 1. С. 209-214.

16. Поспех Е., Шапелявы М., Войнар Ю., Костюченко В. Мнения и ожидания учащихся в оценке предмета "физическое воспитание" в школах стран Европы. Физическая культура. 2002. № 3. C. $3-20$

17. Турчик I.X. Фізичне виховання і спорт у шкільній освіті Англії: дис....канд. наук з фіз. виховання і спорту: 24.00.02; Львівський держ. ін-т фізичної культури. Л., 2005. 207 с.

18. Яковенко А.В. Предмет «Фізична культура» у системі середньої освіти зарубіжних країн. Науковий часопис Національного педагогічного університету імені М.П. Драгоманова. Серія 15: Науково-педагогічні проблеми фізичної культури (фізична культура і спорт). 2018. Вип. 2 (96). C. 112-116.

19. Annerstedt C. Health related Physical Education in
7. Do Keon Vu. (2000). Physical Education Management in Far East Asia: author's abstract of dis ... Candidate of Pedagogical Sciences: 13.00.04; St. Petersburg, 20. (In Russian).

8. Zhdanova O., Chehovska L., Flyak A. (2015). Physical education in schools in Europe. Young sport science of Ukraine, 2, 311-319. (In Ukrainian).

9. Zaburdaeva M. (2007). Structural and content components of the curriculum for the physical education of schoolchildren in Russia and Eastern countries: diss. ... Candidate of Pedagogical Sciences: 13.00.04; St. Petersburg, 240. (In Russian).

10. Ivanov V., Salkova N. (2017). Features of physical culture and sports in Asia. Physical culture. Sports. Tourism. Motor recreation, 2, 1, 32-35. (In Russian).

11. Li Van Tek. (2005). The objectives and content of the physical education of students of secondary schools in Asia (Japan, Korea, China): author's abstract of dis ... Candidate of Pedagogical Sciences: 13.00.04; St. Petersburg, 26. (In Russian).

12. Lifey Hu. (2013). Characteristic features of the functioning of the system of physical culture and sports in the PRC (1995-2012). Physical education, sport and health culture in modern society, 4 (24), 14-18. (In Russian).

13. Mandyuk A. (2013). Physical education in the US secondary education system. Sports newsletter of Pridniprov'ya, 2, 210-213. (In Ukrainian).

14. Pangelova N., Vlasova S. (2017). Foreign experience in organizing physical education in secondary schools. Sports newsletter of Pridniprov'ya, 1, 215221. (In Ukrainian).

15. Pangelova N., Krasov O. (2017). Author's schools and concepts of physical education of preschool children in the new time (mid-XVII - early XX century.). Sports newsletter of Pridniprov'ya, 1, 209214. (In Ukrainian).

16. Pospeh E., Shapelyavyi M., Voynar Yu., Kostyuchenko V. (2002). Opinions and expectations of students in the assessment of the subject of "physical education" in schools in Europe. Physical culture, 3, 3-20. (In Russian).

17. Turchik I. (2005). Physical education and sports in school education in England. diss. ... Candidate of Sciences of Physical education and sports: 24.00.02; Lviv, 207. (In Ukrainian).

18. Yakovenko A. (2018). Subject "Physical Culture" in the system of secondary education of foreign countries. Scientific journal of the National Pedagogical University named after M.P. Dragomanov. Series 15: Scientific and pedagogical problems of physical culture (physical culture and sports), 2 (96), 112-116. (In Ukrainian).

19. Annerstedt C. (2001). Health related Physical

(C) Moskalenko N., Yakovenko A., Ovcharenko S., Natalija G., 2019 
Sweden: Lessons from central governmental transition to local school responsibility. Physical Education: From Central Governmental Regulation to Local School Autonomy. Velen: EADS. 2001. P. 123-138.

20. Hardman K. et al. World-wide survey of school physical education: final Report. 2014. Paris, France: UNESCO. P. 131.

21. Hardman K. The Situation of Physical Education in Schools: a European Perspective. Human movement. 2008. vol. 9 (1). P. 5-18. doi: 10.2478/ v10038-008-0001-z

22. Kajanus A. Physical education in Chinese schools. Role Models, Repetition, and Winning. Education About Asia. Fall 2016. Volume 21. Number 2. P. 5-8.

23. Kelso Ch. The Importance of Physical Education. http://www.veanea.org/home/1000.htm

24. Kilborn M., Lorusso J., Francis N. An analysis of Canadian physical education curricula. European Physical Education Review. 2016. Vol. 22 (1). P. 23-46. DOI: 10.1177/1356336X15586909

25. Nakai T., Metzler M.W. Standarts and Practice for K-12 Physical Education in Japan. Journal of Physical Education, Recreation and Dance. 2005. Vol. 76. №7. P. 17-22.

26. Naul R. Concepts of Physical Education in Europe. Physical Education: Deconstruction and Reconstruction. Issues and Directions, Edition: 1st, Publisher: Schorndorf: Hofmann, Editors: Hardman K., pp.35-52. https://www.researchgate.net/publication/260096002_Concepts_of_Physical_Education_in_Europe

27. Vass Z., Boronyai Z., Csanyi T. European Framework of Quality Physical Education. European Physical Education Association. 2018. 24 p.

28. World-wide Survey of School Physical Education: Final Report 2013 / C. Murphy, A. Routen, S. Tones. Published in 2014 by the United Nations Educational, Scientific and Cultural Organization, UNESCO 2014. 130 p.

\section{Москаленко Наталія}

Придніпровська державна академія фізичної культури і спорту

м. Дніпро, вул. Набережна Перемоги, 10; 49094, Україна

e-mail: moskalenkonatali2016@gmail.com

\section{Яковенко Артем}

Придніпровська державна академія фізичної культури і спорту

м. Дніпро, вул. Набережна Перемоги, 10; 49094, Україна

e-mail: yakovenkoartem2012@gmail.com

\section{Овчаренко Сергій}

Придніпровська державна академія фізичної культури і спорту
Education in Sweden: Lessons from central governmental transition to local school responsibility. Physical Education: From Central Govemmental Regulation to Local School Autonomy. Velen: EADS, 123-138.

20. Hardman K. et al. (2014). World-wide survey of school physical education: final Report. Paris, France: UNESCO, 131.

21. Hardman K. (2008). The Situation of Physical Education in Schools: a European Perspective. Human movement, 9 (1), 5-18. doi: 10.2478/v10038-0080001-z

22. Kajanus A. (2016). Physical education in Chinese schools. Role Models, Repetition, and Winning. Education About Asia, 21, 2, 5-8.

23. Kelso Ch. (2013). The Importance of Physical Education. http://www.veanea.org/home/1000.htm

24. Kilborn M., Lorusso J., Francis N. (2016). An analysis of Canadian physical education curricula. European Physical Education Review, 22 (1), 23-46. DOI: $10.1177 / 1356336 X 15586909$

25. Nakai T., Metzler M.W. (2005). Standarts and Practice for K-12 Physical Education in Japan. Journal of Physical Education, Recreation and Dance, 76, 17-22.

26. Naul R. (2002). Concepts of Physical Education in Europe. PhysicalEducation: Deconstruction and Reconstruction. Issues and Directions, 35-52. https:// www.researchgate.net/publication/260096002_ Concepts of Physical Education in Europe

27. Vass Z., Boronyai Z., Csanyi T. (2018). European Framework of Quality Physical Education. European Physical Education Association, 24.

28. World-wide Survey of School Physical Education: Final Report 2013 / C. Murphy, A. Routen, S. Tones. Published in 2014 by the United Nations Educational, Scientific and Cultural Organization, UNESCO, 130.

м. Дніпро, вул. Набережна Перемоги, 10; 49094, Україна

\section{Natalija Gustavson}

PhD (Pedagogical Sciences),

Koulutuksen arviointikeskus

PL 9 (Siltavuorenpenger 3A)

00014 Helsingin yliopisto

Puhelin 0503182185

Centre for Educational Assessment

Faculty of Educational Sciences

P.O. Box 9 (Siltavuorenpenger 3 A)

FI-00014 University of Helsinki, Finland 